\title{
BARBOSA, Francisco Salatiel de Alencar. Joaseiro Celeste: tempo e paisagem na devoção ao Padre Cícero. São Paulo: Attar, 2007, 186p.
}

João Everton da Cruz ${ }^{*}$

O livro em epígrafe é muito interessante e faz uma abordagem religiosa singular, tendo como personagem central o romeiro de Joaseiro, cidade no Vale do Cariri cearense, onde Padre Cícero Romão Batista fixou residência a partir de 11 de abril de 1872.

O romeiro é o agente do movimento religioso. Com um comportamento atuante, sempre em movimento, numa semiose ilimitada (ilimitada possibilidade de ressignificações), ele é o signo flutuante no processo da romaria. O tema do estudo de Francisco Barbosa é o romeiro de Joaseiro, que tem como pastor e conselheiro o Padre Cícero. As falas dos romeiros e os versos de cordel, presentes em todo o livro, definem a religiosidade desses fiéis que compõem um cenário de fé.

Joaseiro é a Nova Jerusalém; há uma busca da "Jerusalém da Bíblia judeu cristã e Roma da tradição católica, Nova Jerusalém e Roma dos Pobres”. A Nova Jerusalém ergue-se na base tríplice: o sonho, o milagre e a guerra.

Conta-se que certo dia, em Joaseiro, Padre Cícero, cansado dos trabalhos diários, sentou-se e adormeceu reclinado sobre uma mesa; sonhou que Jesus the apareceu, acompanhado dos doze apóstolos, como na Santa Ceia, de Leonardo da Vinci. No quadro, há também um grupo de flagelados, maltrapilhos e esfomeados. Jesus diz a Padre Cícero: “E tu, Cícero, cuida deles!” Assim, ele decidiu ficar no povoado.

Joaseiro começa a ser considerada cidade santa, a Nova Jerusalém, após o milagre acontecido com a beata Maria Magdalena do Espírito Santo de Araújo: quando ela recebia a comunhão, a hóstia sangrava. Isto se repetiu por cerca de dois anos, e foi motivo de se formarem romarias de todas as partes do Nordeste para Joaseiro.

A Igreja tentou de todo modo desmentir o milagre. Padre Cícero foi afastado de suas funções sacerdotais; a Igreja exigiu que ele e também a beata Maria de Araújo

\footnotetext{
* Mestrando em Ciências da Religião pela PUC Minas, e-mail: jooevertoncruz@yahoo.com.br
} 
saíssem de Joaseiro. Mas a Nova Jerusalém já estava erguida. Mas para o povo, Padre Cícero "está vivo no coração do romeiro, como romeiro, pois a romaria é o coração do romeiro".

Padre Cícero teve o papel de pastor do seu povo, defendendo Joaseiro na luta pela emancipação do município de Crato, reunindo os chefes políticos para um acordo o Pacto dos Coronéis do Cariri - em 4 de outubro de 1911. O Pacto dos Coronéis, feito com a posse de Padre Cícero como prefeito de Joaseiro, teve como finalidade manter a ordem e evitar confrontos entre os municípios do Vale do Cariri.

O ingresso de Pe. Cícero na política visava tão somente resguardar seu projeto sociorreligioso, que era a "cidade santa" de Joaseiro, desenvolvida a partir dos fatos extraordinários de 1889. Para isso, contou com o apoio do político e médico baiano Floro Bartolomeu, que foi seu aliado. A revolta de Joaseiro contra o governador do Ceará, Marcos Franco Rabelo, deveu seu êxito à atuação do Padre - êxito registrado inclusive nos versos de cordéis. Essa batalha travada pelos principais políticos locais tem, nas narrativas do povo do Nordeste, um caráter místico: nelas aparece a figura do mal, de Satanás, contra o qual foi preciso lutar, contando com a proteção divina. A revolta política é comandada por homens influentes do lugar, e tem o apoio do povo, junto com o Padre Cícero, que é religioso e também político. Na batalha, que se reveste de misticismo, o povo conta com a proteção de Nossa Senhora, das bênçãos divinas e do rosário.

A visão de mundo do Padre Cícero insere-se muito mais na linha de uma espiritualidade mística eminente do que na de uma lógica política constituída por estratégias em torno do jogo do poder. A condução política do Joaseiro foi sempre confiada pelo Pe. Cícero a um interlocutor mais acostumado com a lógica da política, como o Pe. Peixoto, que se empenhou no movimento pela emancipação política de Joaseiro, ou Floro, encarregado das relações com a oligarquia regional e o Governo Federal. Pe. Cícero foi sempre movido pela idéia da pacificação.

Segundo os romeiros, ainda hoje o santo conselheiro, como o consideram, ajuda as pessoas que a ele recorrem para resolver seus problemas na vida cotidiana. Símbolos religiosos ligam os romeiros à devoção ao Padrinho - denominação pela qual é designado -, como o rosário, o cajado, o chapéu de palha. A Casa Museu do Padrinho e o seu túmulo na Capela do Socorro são lugares de visita das romarias. Na Serra do 
Horto, os romeiros fazem sua penitência, passando por caminhos estreitos, sem sombras para aliviá-los. Existe o ritual de passar por um trecho entre blocos de pedras, o que exige cuidado e paciência. Muitos romeiros cumprem esse ritual para se purificarem dos pecados.

Padre Cícero foi um homem de fé, que assumiu o papel de guia do seu povo. Foi conselheiro e pastor. Participava integralmente dos problemas da sua comunidade. Nesse sentido, foi um cristão verdadeiro.

O professor e pesquisador social autor da obra em comento - versão da tese de doutoramento defendida no Departamento de Antropologia da Universidade de Brasília - dedica um capítulo à definição da figura de Padre Cícero junto aos romeiros, denominando-o romeiro por antonomásia, acentuando o tipo de liderança espiritual ou mística [cap. 7], "que, de certo modo, transforma ou renomeia o Padrinho, tido por seus envolvidos políticos como um coronel”. Ele deixou o legado da fé e da perseverança, presentes no coração dos romeiros até os dias de hoje.

Padre Cícero é comparado a Moisés, por sua missão de guia de seu povo. Para o romeiro, a esfera celestial sobrepõe-se a todas as outras; assim, o Padrinho tem, para ele, um significado místico, que é o de ser santo, muito mais importante do que ter sido um político ou clérigo.

O livro oferece espaço para uma interpretação de que o Padre Cícero Romão Batista era uma pessoa integrada e com uma personalidade equilibrada, pois soube lidar com diferentes interlocutores, desde os mais pobres e iletrados até com os representantes das elites e intelectuais da época.

Não há, na obra, julgamento de valor da religiosidade popular. Ela constitui antes uma mostra da expressão dos fiéis, dos romeiros que buscam em sua crença religiosa manter viva sua identidade cultural e sua cidadania. Também ao conservar, no título, a grafia antiga da palavra Joaseiro, recuperando o sentido primeiro do vocábulo derivado de joá, nome do fruto produzido por essa árvore, própria da região -, o autor confirma sua intenção de resgate de valores culturais nordestinos. 